\title{
Can computers form cartels? About the need for European institutions to revise the concertation doctrine in the information age
}

\author{
Gebicka, Aleksandra ; Heinemann, Andreas
}

\begin{abstract}
Traditionally, the European Commission and the European courts have considered that a concertation arises as soon as information is exchanged among competitors. That approach creates difficulties on information based markets where computers and more generally machines systematically organise such exchanges and may thus give rise to allegations of cartel infringement for their operators, despite the absence of any fraudulous intention whatsoever on the part of the latter In our opinion, such development emphasizes the need, for the European institutions, to revisit their doctrine, and their jurisprudence, on the formation of anticompetitive coordination.
\end{abstract}

DOI: https://doi.org/10.1093/jeclap/lpw036

Posted at the Zurich Open Repository and Archive, University of Zurich ZORA URL: https://doi.org/10.5167/uzh-129311

Journal Article

Accepted Version

Originally published at:

Gebicka, Aleksandra; Heinemann, Andreas (2016). Can computers form cartels? About the need for European institutions to revise the concertation doctrine in the information age. Journal of European Competition Law and Practice, (7):431-441.

DOI: https://doi.org/10.1093/jeclap/lpw036 


\title{
Can Computers Form Cartels? About the Need for European Institutions to Revise the Concertation Doctrine in the Information Age
}

\author{
ANDREAS HEINEMANN* \\ ALEKSANDRA GEBICKA **
}

\section{KEY POINTS}

Traditionally, the European Commission and the European courts have considered that a concertation arises as soon as information is exchanged among competitors.

That approach creates difficulties on information based markets where computers and more generally machines systematically organise such exchanges and may thus give rise to allegations of cartel infringement for their operators, despite the absence of any fraudulous intention whatsoever on the part of the latter

In our opinion, such development emphasizes the need, for the European institutions, to revisit their doctrine, and their jurisprudence, on the formation of anticompetitive coordination.

\section{Restrictive Practices in a Computerised World}

Faced with the growing computerisation of commercial activities, Competition Law is required to develop and modernise its analytical toolkit to adapt to new situations that arise thanks to the use of computers and online services. So far, the discussion has focused on two aspects of this growing phenomenon. On the one hand, there is the general question whether traditional Competition Law is capable of coping with the particular features of the digital economy, and on the other hand how it would apply to specific manifestations of information and communication technologies (ICT), for instance hardware and software markets, e-commerce, search engines, social media and big data. ${ }^{1}$

Professor of Commercial, Economic and European Law at the University of Zurich. Email: andreas.heinemann@rwi.uzh.ch.

** LL.M. in European and Comparative Law, Humboldt University of Berlin, Maîtrise 1 in European Law, University Paris 2 Panthéon-Assas. Email: aleksandra.gebicka@wycliffe.pl.

$1 \quad$ See for example Massimiliano Kadar, European Union Competition Law in the Digital Era, Zeitschrift für Wettbewerbsrecht (ZWeR) 2015, 342; Gintare Surblyte, Competition Law at the Crossroads in the Digital Economy: Is it All About Google?, Max Planck Institute for Innovation and Competition Research Paper No. 15-13 <http://papers.ssrn.com/sol3/papers.cfm?abstract_id=2701847>. See also the special report of the German Monopolies Commission on the challenge of digital markets, English summary available at <http://www.monopolkommission.de/images/PDF/SG/SG68/S68_summary.pdf>. 
The 2016 judgment of the European Court of Justice (ECJ) ${ }^{2}$ in the case of Eturas and others shows that technological advances also constitute a challenge to the vocabulary employed by Competition Law, in particular to the categories of 'agreement' and 'concerted practices', which are at the core of the cartel and collusion prohibition of Art. 101 TFEU. Outside of the field of merger control, firms which are not dominant can only violate European Competition Law if they conclude an agreement or have recourse to concerted practices with the object or effect of restriction of competition and affectation of cross-border trade in the EU or the EEA. ${ }^{3}$ For this reason, a clear understanding of these terms is fundamental. In an unwavering line of case law, the ECJ has consistently and invariably interpreted the term 'agreement' as the "expression of the joint intention of the parties" which also extends to gentlemen's agreements, i.e. to commitments which are not based on legal, but rather on 'moral' considerations. ${ }^{4}$ There has to be "concurrence of wills" even if details of the agreement have still to be finalised. ${ }^{5}$ The participation in a collusive meeting creates a presumption of illegality which can be rebutted by public distancing "which must be perceived as such by the other parties to the cartel". ${ }^{6}$ The concept of concerted practices, on the other hand, "refers to a form of coordination between undertakings, which, without having been taken to the stage where an agreement properly so-called has been concluded, knowingly substitutes for the risks of competition, practical cooperation between them which leads to conditions of competition which do not correspond to the normal conditions of the market". ${ }^{7}$ In practice, this type of restriction is applied where wilful coordination takes place while the existence of an agreement cannot be proved, or where the parties behave in a concerted manner without having gone as far as to reach an agreement. The distinction between (illegal) concerted practices and a mere parallelism of conduct, for example based on one undertaking's observations of its competitors' behaviour in the market, is not always an easy one to draw.

As undertakings continue to expand their ICT applications to a growing number of sectors, it has become possible to influence prices and other parameters of competition through appropriate programming. While Competition Law addresses 'undertakings', ie. legal entities like companies and businesses, it is notable that the traditional definitions of agreements and concerted practices, which

2 ECJ, 21.1.2016, C-74/14 - Eturas and others, ECLI:EU:C:2016:42 ("ECJ - Eturas").

Art. 101(1) TFEU and Art. 53(1) EEA-Agreement; most of the EU Member States (and of the Contracting Parties of the EEA) have taken over these terms in their national Competition Law, see e.g. Art. L420-1 of the French Commercial Code, Section 2 (1) of the British Competition Act 1998 and $\S 1$ of the German Act Against Restraints of Competition (GWB).

4 ECJ, 15.7.1970, 41/69 - Chemiefarma/Commission, ECLI:EU:C:1970:71, n. 112.

General Court, 13.9.2013, T-566/08 - Total Raffinage Marketing/Commission, ECLI:EU:T:2013:423, n. 32.

ECJ, 17.9.2015, C-634/13 P, Total Marketing Services/Commission, ECLI:EU:C:2015:614, n. 21.

ECJ, 16.12.1975, Joined Cases 40 to 48, 50, 54 to 56, 111, 113 and 114/73 - Suiker Unie and others/Commission, ECLI:EU:C:1975:174, n. 26. 
use terms like 'concurrence of wills', 'meeting of the minds' and 'coordination', refer to physical human beings within the firms. In the digital economy, it is becoming increasingly challenging to transfer these subjective concepts to computerised systems which necessitate human intervention less and less. The Eturas case is the first opportunity for the ECJ to specify the conditions of the application of EU Competition Law to automated processes.

\section{Online booking platforms}

\section{Facts}

The case concerned 30 travel agencies in Lithuania that were all using an online booking system called E-TURAS, owned by the travel agency Eturas. ${ }^{8}$ Through the E-TURAS booking system, Eturas imposed on the other agencies a technical restriction on the discount rates they could offer their own clients, and posted a notice informing its 30 users about it. The Lithuanian Competition Council launched an investigation after receiving word from one of the travel agencies, attracting its attention to the fact that all 30 of them were using E-TURAS to coordinate discounts offered to end consumers, which the system automatically limited to 3\%. Discounts in excess of $3 \%$ were automatically reduced to $3 \%$ by the system. Although additional discounts to individual clients remained possible, the majority of agencies which granted higher discounts beforehand decreased the discount rate to $3 \%$ after the change.

The Lithuanian Competition Council found that the 30 agencies had participated in a concerted practice that infringed Art. 101(1) TFEU as well as Lithuanian Competition Law on the same matter. The Competition Council fined all of the participants except the agency that informed it of the practice. The case was appealed all the way up to the Supreme Administrative Court of Lithuania.

The agencies argued that they had not engaged in concerted practices such as prohibited by Art. 101(1) TFEU or national Competition Law. Their stance was that the restriction on the discounts was a technical unilateral act by Eturas, involving no will or intention on their part. Regarding their intention, some claimed not to have read the information Eturas posted about limiting the discount rates. Other arguments included only fractionally relying on E-TURAS in their business activities and the maintained possibility of loyalty discounts in excess of $3 \%$ for the agencies' clients. A

\footnotetext{
$8 \quad$ For the purposes of clarity and in order to respect the original spelling, the name "Eturas" refers to the travel agency, while the term "E-TURAS" refers to the online booking system shared by all concerned agencies.
} 
worrying statement revealed that the agencies used the E-TURAS booking system because it was convenient for online sales when there were no alternative choices on the market.

On the other hand, the Lithuanian Competition Council argued that E-TURAS was a platform for the concerted practice to operate in, that it allowed 'concurrence of the wills' while avoiding direct contact, and that the agencies failed to effectively oppose the discount restriction. Their own economic activities were affected and the knowledge of the limitation eliminated uncertainty in the economic activity of their competitors. Normally, in the travel agencies market, it could be expected that competing agencies would fight for clients by offering discounts.

\section{The traditional position on concertation}

\section{a) Starting Point}

In the judgment, the Court reiterates the rationale behind the prohibition of restrictive agreements: according to the long-established requirement of independence ${ }^{9}$, each economic operator must autonomously determine the policy which it intends to adopt on the internal market, without knowledge of how its competitors will behave. Direct or indirect contacts between undertakings are precluded, regardless of whether if they are supposed to influence competitors or just to inform them about one's own conduct, "where the object or effect of those contacts is to give rise to conditions of competition which do not correspond to the normal conditions of the market in question" ${ }^{10}$ The Court also mentions the application of Competition Law to passive behaviour: participation in anticompetitive meetings is indicative of collusion if the firm does not publicly distance itself or does not report the event to the competent authority. ${ }^{11}$

As regards the burden of proof, the Court points to Art. 2 Regulation No 1/2003, which allocates the burden of proving an infringement of Art. 101(1) TFEU on the party or the authority alleging the infringement, and the burden of proving a justification based on Art. 101(3) TFEU on the defendant. Still, a distinction has to be made in this context. EU law including Art. 2 Regulation No 1/2003 only gives general rules. The Regulation does not address more specific aspects, in particular the principles

\footnotetext{
9 See AG Szpunar, 16.7.2015, C-74/14 - Eturas and others, ECLI:EU:C:2016:42, n. 32. The requirement of independence (in German: "Selbständigkeitspostulat") is at least recognized since ECJ, 16.12.1975, Joined Cases 40 to 48, 50, 54 to 56, 111, 113 and 114/73 - Suiker Unie and others/Commission, ECLI:EU:C:1975:174, n. 174. The English terminology is not uniform: In the Eturas judgment, the ECJ also uses the term of "requirement of autonomy", see ECJ Eturas, n. 27.

$10 \quad$ ECJ - Eturas, n. 27.

11 ECJ-Eturas, n. 28
} 
governing the assessment of evidence and the standard of proof in national proceedings. ${ }^{12}$ Hence, these questions are part of the procedural autonomy of Members States. When filling in these gaps, however, the latter have to respect the principle of equivalence (the procedure for cases of EU law must be equivalent to the one involving national law) and of effectiveness (no excessive requirements for exercising rights conferred by EU law so as to render EU law ineffective). ${ }^{13}$

With respect to concerted practices, the distribution of competences between EU and national law has the following consequence: on the one hand, there are basic rules which form "an integral part of the EU law which the national court is required to apply". ${ }^{14}$ An example of a rule on the EU level is the so-called Anic presumption, ${ }^{15}$ according to which a causal connection is presumed once the concertation and a corresponding behaviour have been shown. ${ }^{16}$ On the other hand, the rules on the assessment of evidence and the standard of proof are up to national law, even though it must respect the EU principles of equivalence and effectiveness.

\section{b) Application to an Online Booking System}

The ECJ applies this framework to the information flow in an online booking system and makes some important distinctions in this context. Their importance can best be understood if a clear separation between the three conditions of a concerted practice is made: concertation, subsequent conduct and the causal link between them.

\section{Concertation}

The Anic presumption refers to the causal link between concertation and subsequent conduct, not to the existence of concertation itself. Consequently, the Court attributes the question of concertation to the assessment of evidence and the standard of proof, so that national law has to give the answer. ${ }^{17}$ Therefore, it is up to national law to decide if the dispatch of a message in an online booking system is sufficient to prove that the addressees were aware, or ought to have been aware, of its content. ${ }^{18}$ However, the (EU-law based) principle of effectiveness requires that concertation may not only be proven by direct evidence but can also be inferred from "coincidences and indicia" if they are

\footnotetext{
12 ECJ - Eturas, n. 29-30; see also Recital 5 of Regulation No 1/2003.

13 ECJ - Eturas, n. 32. See also previous case law, for instance ECJ, 10.07.1999, C-261/95 - Rosalba Palmisani $v$ Istituto nazionale della previdenza sociale (INPS), ECLI:EU:C:1997:351, n. 27.

$14 \quad$ ECJ - Eturas, n. 33.

15 ECJ, 8.7.1999, C-49/92 P - Commission/Anic Partecipazioni, ECLI:EU:C:1999:356, n. 121; cf. AG Szpunar Eturas, n. 33.

$16 \quad$ ECJ - Eturas, n. 33.

17 ECJ-Eturas, n. 34.

18 Ibid.
} 
objective and consistent. ${ }^{19}$ Furthermore, such indirect evidence must comply with the presumption of innocence (Art. 48(1) EU Charter of Fundamental Rights). Therefore, it is not allowed to deduce awareness of one actor from the mere dispatch of the message in the booking system by another actor. Nevertheless, the presumption of innocence "does not preclude the referring court" from using "other objective and consistent indicia" for a presumption of awareness. Firms may rebut this presumption "for example by proving that they did not receive that message or that they did not look at the section in question or did not look at it until some time had passed since that dispatch". ${ }^{20}$ This reasoning, while logical, does indeed rest on the firm's ability to demonstrate that they did not know something, which might be difficult to prove.

\section{Subsequent Conduct}

The ECJ does not explicitly deal with subsequent conduct. Typically, the behaviour following a concertation is raising prices or reducing output. In this context, the Court mentions the implementation of the software limiting discounts to $3 \%$. It takes into consideration the possibility for the agencies to grant higher discounts, but underlines the fact that the system nevertheless requires them "to take additional technical steps in order to do so". ${ }^{21}$ No further details are given. ${ }^{22}$ Instead, the importance of being aware of the system notice's content is reiterated. ${ }^{23} \mathrm{In}$ sum, the requirements concerning subsequent conduct seem to be less developed than those for the concertation and the causal link.

\section{Causal Link between Concertation and Subsequent Conduct}

As mentioned above, the relationship of cause and effect is presumed once the concertation and the subsequent conduct on the market have been shown. ${ }^{24}$ According to established case law, ${ }^{25}$ an undertaking may rebut the presumption by publicly distancing itself from it or by reporting it to the administrative authorities. The ECJ specifies that in the case of an online booking system where the addressees of a system notice do not know each other it is not necessary to send declarations to everybody. It is sufficient that an objection is sent to the administrator of that system. ${ }^{26}$ If the coordination does not take place in the form of a meeting, other circumstances allow the rebuttal of

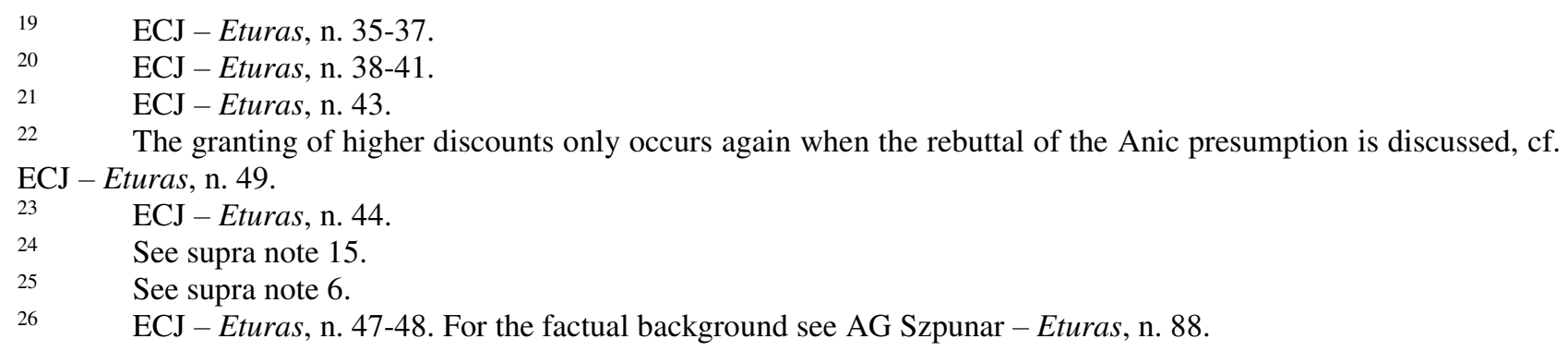


the presumption, for instance proof that consistently higher discounts have been granted, above those allowed by the system. ${ }^{27}$

\section{c) Giving rise to a presumption}

Price-related measures implemented in online booking systems used by competitors may give rise to the presumption of an illicit concerted practice. This may occur even if the measure is implemented by a single user without asking for the others' input or opinion. This is even more so the case if the administrator of that system posts a message in the users' system mailboxes revealing an intention to cap discounts, if this notice is then followed by a technical restriction that implements the announced discount limit, and finally if the users are aware of that message. Awareness may not be deduced from the mere dispatch of the message in the mailbox of that system. However, awareness may be inferred from indirect evidence. Once awareness has been established, the existence of a concerted practice is presumed unless the parties rebut this presumption by publicly distancing themselves from the anticompetitive initiative, by reporting it to the authorities or by showing that discounts exceeding the cap have been practiced repeatedly and methodically. In our view proof of an intention to actively counter-act the restriction would also be beneficial.

\section{IT systems and cartel prohibition}

The Eturas case breaks new ground. The ECJ gives some guidance regarding the conditions under which the design of IT systems enters into conflict with the cartel prohibition. The case touches upon price-related features of online booking systems, in particular the determination of discounts. Interfering with the freedom of price determination may very well lead to an illegal collusion between the users of that system. The Court tries to apply the requirements of Art. 101(1) TFEU to computerised sales systems. In spite of increasing automatisation, it is the 'awareness' of the participants which is at the heart of the analysis. In the following analysis, the different elements of these findings shall be examined.

$27 \quad$ ECJ - Eturas, n. 46, 49. 


\section{Concertation}

\section{a) Coordination in online booking systems}

At the heart of the case stands the "unusual method of communication" between the undertakings concerned. ${ }^{28}$ The accusation of collusion is not based on standard commercial dialogue through emails or meetings, but on a message sent by the E-TURAS booking system administrator to the users of that system and which arrived in a mailbox specifically reserved to that system. ${ }^{29}$ That inbox is protected by an individual online password, and the message there can be opened by the users of the system. Most crucially in question are the conditions in which such intra-system messages amount to a coordination between competing firms. At first sight, the sending of the message by the system administrator is unilateral conduct. Of course, the parties raised this argument, ${ }^{30}$ but the Court probably due to the specific formulation of the preliminary questions - did not directly react to this problem. Implicitly, the Court starts from the idea that concertation exists where the users of the online booking system are aware of the system message.

Advocate General Szpunar discusses this question in more depth and focuses on the existence of consensus without requiring a high degree of formalisation. One of the special circumstances of the case is the fact that the travel agencies did not explicitly answer the system message announcing the cap of discount rates. There was no unequivocal approval. However, the absence of response may mean acquiescence where "the circumstances are propitious to the formation of a tacit consensus". ${ }^{31}$ In this context, it is important to note that the sender of the system message is not a competitor but the rightful owner of the online booking system who has concluded valid licensing agreements with the travel agencies allowing them the use of the system. The Advocate General suggests that in a situation where the sender of the message is not a competitor but a third party, horizontal collusion takes place if the message comes from a competitor "or at least is also communicated to a competitor" thus giving rise to mutual action even in absence of response. ${ }^{32}$

This interpretation seems convincing. The mechanism by which competitors coordinate their pricing behaviour is of secondary importance. It is the very goal of the expression 'concerted practices' - a modality to cover all methods of wilful cooperation. The three forms of collusion mentioned in Art. 101(1) TFEU (agreements, decisions by associations, concerted practices) are comparable "and

AG Szpunar-Eturas, n. 53.

The peculiarity of this form of communication is underlined by AG Szpunar-Eturas, n. 60 .

See ECJ - Eturas, n. 19.

AG Szpunar - Eturas, n. 46-49.

AG Szpunar-Eturas, n. 50-51. 
are only distinguishable from each other by their intensity and the forms in which they manifest themselves". ${ }^{33}$ Therefore, the fact that a third party - who is not a competitor - plays a major role in the horizontal coordination is not a decisive factor. It is only important if the competing agencies reach a coordination among themselves through the intervention of that third party. In this context, it has to be underlined that the system message announcing the discount cap did not come out of the blue. Evidence shows that there had been prior communication between Eturas and the travel agencies regarding a possible reduction of discount rates. ${ }^{34}$ The agencies were participating in a common booking system, there was a notice informing of the discount restriction and the agencies remained active on their market after the restriction was automatically implemented in the E-TURAS system. In sum, the Court was right to reject the argument that the discount restriction was a unilateral act by Eturas.

\section{b) Unilateral Behaviour in a Contractual Relationship}

The case law on unilateral acts within a standing contractual relationship is ambiguous. In several cases, the ECJ has qualified apparently unilateral acts within a distribution system as part of the agreement "inasmuch as their purpose is to guarantee observance of the agreements in restraint of competition". ${ }^{35}$ In other cases, concurrence of wills was rejected. An example is the Bayer case in which the European Commission had described as restrictive agreements supply restrictions imposed by a pharmaceutical company in order to prevent parallel imports. The Court, however, did not share this view: the mere coexistence of a distribution agreement and a unilaterally imposed supply restriction does not, according to the Court, make the supply restriction part of an agreement in the sense of Competition Law. ${ }^{36}$

The Bayer decision is doubtful since the interaction of stimulus and response in this case would have allowed at least the finding of concerted practices. ${ }^{37}$ For the purposes of our analysis, it is sufficient to note that no contradiction between the Eturas and the Bayer cases arises. ${ }^{38}$ The Bayer case concerns vertical relationships where a supplier takes (apparently) unilateral measures which complement a distribution agreement compatible with Competition Law. In the Eturas case, however, the system

\footnotetext{
33 ECJ, 8.7.1999, C-49/92 P - Commission/Anic Partecipazioni, ECLI:EU:C:1999:356, n. 131.

34 See the indications of AG Szpunar-Eturas, n. 75-78.

35 ECJ, 25.10.1983, 107/82 - AEG/Commission, ECLI:EU:C:1983:293, n. 39; see the summary of the case law in General Court, 9.7.2009, T-450/05 - Peugeot and Peugeot Nederland/Commission, ECLI:EU:T:2009:262, n. 168 et seq. 36 ECJ, 6.1.2004, Joined Cases C-2/01 P and C-3/01 P - BAI and Commission/Bayer, ECLI:EU:C:2004:2, n. 96 et seq., 140 et seq.

37 See Andreas Heinemann, Intellectual Property Rights and Market Integration, in: Anderman/Ezrachi (eds.), Intellectual Property and Competition Law: New Frontiers, Oxford 2011, p. 308-309.

$38 \quad$ Also in this sense AG Szpunar-Eturas, n. 64 who explains the difference to a hub-and-spoke system in n. 65.
} 
message is used to coordinate the discount policy of the members of that system. Technical means reinforce the effectiveness of that coordination. The very goal of this mechanism is coordination in a horizontal relationship which is facilitated by the interference of the system administrator. Following the T-Mobile Netherlands case, ${ }^{39}$ the Advocate General argued that also in the Eturas case one selective manipulation of one parameter of competition occurred which was sufficient to violate Art. 101(1) TFEU. ${ }^{40}$ In our view, however, the coordination in the Eturas case cannot be compared to a 'single meeting'. The technical change in the computer system takes place on a lasting basis. Regular meetings are replaced by a permanent IT-mechanism capping discounts at 3\%. Even more complex objects of coordination could be covered by such an instrument. The one-off alteration of an IT system often is much more inclusive and effective than a single meeting in the real world, and its restrictive scope extends substantially further in breadth and time. Thus, it does not seem necessary for us to point to the 'one meeting' situation of the T-Mobile Netherlands case in order to find concerted practices in the Eturas constellation.

\section{c) Awareness}

Concertation is at the heart of the Eturas case. Although not expressly stated, the message of the judgment seems to be that concertation is not imaginable without awareness of the system notice announcing the cap of the discount rate. The ECJ deals primarily with questions of proof: Awareness cannot be derived from the mere dispatch of the message in the booking system. On the other hand, direct proof is not necessary, but awareness can be shown by means of indicia, always provided that the accused firm has the possibility to rebut the ensuing presumption by showing for example that it did not open the message.

These principles are well-balanced and deserve approval, but they hide an inaccuracy of the Eturas decision. The referring national court asks in its preliminary question if the proof of the system notice allows the presumption that the "economic operators were aware, or ought to have been aware, of the system notice introduced into the computerised information system". ${ }^{41}$ In the context of concerted practices, there is a significant difference between 'was aware' and 'ought to have been aware' since concertation requires that the risks of competition are 'knowingly' substituted by practical cooperation. ${ }^{42}$ Hence, concertation only takes place if there is a wilful activity. Parallel conduct which is not based on conscious coordination - but for instance on observation of the behaviour of

\footnotetext{
39 See ECJ, 4.6.2009, C-8/08 - T-Mobile Netherlands and others, ECLI:EU:C:2009:343, n. 60, 62.

$40 \quad$ AG Szpunar-Eturas, n. 66.

41 ECJ-Eturas, n. 25, Question 1.

$42 \quad$ See supra at note 7.
} 
competitors - does not violate Art. 101 TFEU even if the application of the diligence required had revealed the overarching cartel scheme. The Court does not distinguish between 'was aware' and 'ought to have been aware', but mentions the two alternatives at several points in the same breath. ${ }^{43}$

It is the authors' view that this is not compatible with the fundamental goal of Art. 101 TFEU which aims at preventing a meeting of minds in an anti-competitive manner. Hence, it should be clarified that concerted practices only occur where awareness of the restriction can be proven, even if it is by means of (rebuttable) presumptions. For Art. 101 TFEU to be violated it is not sufficient that ignorance of the system notice is due to negligence. Tacit acquiescence also has to be conscious. The Eturas judgment is thus open to this interpretation. In the context of the presumption of innocence, the ECJ does not mention the phrase 'ought to have been aware' any more. ${ }^{44}$ And, more importantly, in the final answer to the preliminary question, the Court requires (actual) awareness in order to trigger the presumption of a concerted practice. ${ }^{45}$ However, this interpretation is not beyond doubt. Indeed, in the second part of the answer, the Court reiterates that the mere dispatch of the message in the computer system does not constitute sufficient evidence that the user of that system "ought to have been aware of its content" ${ }^{46}$ This remark creates confusion as to the precise conditions of a concerted practice. It should be noted that concertation requires actual and not only potential awareness of the measures aiming at a restriction of competition. On the other hand, actual awareness may be proved by indirect evidence, for example indicia, circumstantial evidence and other details of the case. The Court should have made this point clearer.

While the method of communication in the Eturas case is less usual than standard commercial dialogue through emails or meetings, it does not change the fact that it was an initiative to engage in an illicit anti-competitive practice. There was no reaction to the negative by any agency and a maintained continuation of commercial relations by all of them, which was equivalent to tacit acquiescence to the implementation of the restriction in the entire system. Under the circumstances, the undertakings who became aware of the illicit initiative through the notice and who continued to be connected to the system must be held liable for participation in a concerted practice.

\section{Subsequent Conduct and the Causal Link}

In the Eturas case, the focus is clearly on concertation, and less on the subsequent conduct in the market and the causal link between concertation and conduct. This is understandable because it is

\footnotetext{
$43 \quad$ ECJ - Eturas, n. 26, 29, 34, 38, 39.

$44 \quad$ ECJ - Eturas, n. 40.

45 ECJ-Eturas, n. 50, first indent.

46 ECJ - Eturas, n. 50, second indent.
} 
obvious that the technical manipulation of the electronic booking system considerably reduces the room for manœuvre of the travel agencies in day-to-day practice. Even if they remain free to grant additional discounts, this requires supplementary technical steps. Hence, there is no doubt that concertation influenced subsequent behaviour because of the structure of E-TURAS.

\section{a) The Anic presumption}

Nevertheless, the case reveals an inherent difficulty of the Anic presumption. Indeed, it is now unclear whether the presumption refers solely to the causal link between concertation and subsequent behaviour, or whether it extends to the mere existence of subsequent behaviour itself. In its classical formulation, the former interpretation seems correct: it is presumed "that the undertakings participating in concerting arrangements and remaining active on the market take account of the information exchanged with their competitors when determining their conduct on that market". ${ }^{47}$ The ECJ reiterates this formulation in the Eturas judgement. ${ }^{48}$ However, the Advocate General goes one step further. He applies the presumption not only to the causal link but to the subsequent conduct by itself: The "actual conduct on the market may be presumed with regard to those undertakings who participate in collusive practices and who remain active on the market". ${ }^{49}$

In our view, the following distinction should be made: when concertation is based on information exchange (as it was in the Anic case), it is not easy to determine the subsequent behaviour at all. There are simple cases where the information concerns future prices. If all participants of the information exchange conform their prices to the information given, it is feasible to determine that it was the cause of the subsequent behaviour. A 'narrow Anic presumption' which covers only the causal link, but not subsequent conduct itself, is then sufficient. If, however, the information exchange is more subtle, it is difficult to show the extent to which this exchange affects prices, quantities or other competitive behaviour. The principle of effectiveness then requires a 'wide Anic presumption' regarding subsequent conduct itself: the practical cooperation which has replaced the risks of competition may for example prevent the lowering of prices.

Following this line of thought, a 'narrow Anic presumption' should apply in the Eturas case. It is not about the complex consequences of information exchange, but parties suffering an influence on an important price component. Indeed, discount rates are capped automatically by the system, without the agencies' input. The fact that individual discounts exceeding the cap remain possible does not

\footnotetext{
47 ECJ, 8.7.1999, C-49/92 P - Commission/Anic Partecipazioni, ECLI:EU:C:1999:356, n. 121.

$48 \quad$ ECJ - Eturas, n. 33.

$49 \quad$ AG Szpunar-Eturas, n. 41.
} 
dispose of the price cartel. Hence, subsequent conduct can be proven. Consequently, the Anic presumption does not apply to subsequent conduct, but to the causal link between concertation and conduct.

\section{b) Rebuttal of the Presumption Based on Public Distancing}

As mentioned above, public distancing is a way of rebutting the Anic presumption. If firms which are part of a competition-restricting scheme do not clearly show that they disapprove of the unlawful behaviour of the other participants, they give out the impression that they subscribe to and comply with what has been agreed upon. They opt for a "passive mode of participation" encouraging the continuation of the illegal conduct and compromising its discovery. ${ }^{50}$ They then infringe Art. 101 TFEU themselves.

On the facts, the travel agencies did not in any way distance themselves from the system message. They could and should have manifested their disagreement, especially since they could not quit the system for lack of suitable alternative. While complete rupture of business relations with an otherwise legal distribution channel is not required for a distancing to be valid, there must be a timely, clear, public indication of withholding from the anti-competitive behaviour. Arguing that they did not know that the particular behaviour was illegal is not a defence. It was not enough for the agencies to continue offering independent personal discounts to clients to counterbalance the effects of the discount restriction on the E-TURAS system. ${ }^{51}$ In our view, the option accepted by the ECJ of sending an objection to the administrator is not sufficient for public distancing since such a communication stays in the sphere of the administrator. If the addressees of the system notice are not detectable (and high requirements should be applied to this finding), at least the own clients should be informed about the non-respect of the discount cap. ${ }^{52}$

\section{c) Rebuttal of the Presumption Based on Reporting to an Authority}

In addition to public distancing, the Court mentions reporting to an authority as a possibility of rebutting the presumption based on market conduct after the concertation. ${ }^{53}$ In the context of Competition Law, the most common way for cartel participants to report to an authority is an application for leniency leading to a total or at least partial reduction of fines. In our context, a leniency application would have the following effect: because (timely) reporting to the authority

\footnotetext{
$50 \quad$ Cf. ECJ - Eturas, n. 28.

AG Szpunar - Eturas, n. 90-93.

This alternative has been mentioned by AG Szpunar - Eturas, n. 92.

ECJ - Eturas, n. 46, 49 and 50, first indent; AG Szpunar-Eturas, n. 67, 84, 87, 92. This option is not a novelty of the Eturas judgment: Reporting to an authority has for example been mentioned in ECJ, 7.1.2004, C-204/00 P Aalborg Portland and others/Commission, ECLI:EU:C:2004:6, n. 84.
} 
allows the rebuttal of the presumption that the firm in question participated in concerted practices, that firm did not behave in an anti-competitive manner and there is no more accusation for which leniency could be claimed. For practical purposes, this raises the question whether the second leniency applicant (still participating in the collusion) now moves up to the first position leading to full immunity. In our view, there should not be any obstacle to this solution since the first leniency applicant is no longer part of the cartel so that its leniency application grasps at nothing.

\section{d) Rebuttal of the Presumption Based on an Independent Discount Policy}

Finally, the ECJ mentions a third possibility of rebutting the presumption reserved to forms of coordination other than anticompetitive meetings. The parties can show that they systematically acted in contradiction to the proposed or implemented anti-competitive practice. On the facts, this would mean that they applied higher discounts than provided for by the online booking system. ${ }^{54}$ In our view, however, a discount policy which is systematically independent from the automatic pre-setting of the online booking system does not fulfil the requirement of 'subsequent conduct' necessary for the existence of a concerted practice. If the manipulation of the computer system is not followed by corresponding behaviour of its users, then there is no room to apply a presumption of causal link, at least if the Anic presumption is restricted to the question of causation and does not extend to the subsequent conduct itself - as suggested here for cases outside information exchange. Hence, the systematic application of higher discounts already argues against the second element of the concerted practices test so that the question of causation does not arise.

\section{Restrictions by Object}

According to settled case law, it is not necessary to show the negative effects of an agreement if it has an anti-competitive object. ${ }^{55}$ Horizontal price-fixing agreements are normally considered restrictions by object. ${ }^{56}$ This appreciation applies to the case at hand: it is the attempt to influence the free formation of prices by capping discount rates which "manifestly has as its object to restrict competition" ${ }^{57}$ Consequently, authorities and courts do not have to prove anti-competitive effects of that agreement. ${ }^{58}$ For example, it is irrelevant if travel agencies had granted higher discount rates

$54 \quad$ ECJ - Eturas, n. 46, 49 and 50, first indent.

55 See the seminal judgments ECJ, 30.6.1966, 56/65 - Société Technique Minière / Maschinenbau Ulm, ECLI:EU:C:1966:38, p. 249; and ECJ, 13.7.1966, 56/64 - Consten and Grundig/Commission, ECLI:EU:C:1966:41, p. 342 .

56 ECJ, 11.9.2014, C-67/13 P - Groupement des cartes bancaires/Commission, E-CLI:EU:C:2014:2204, n. 51; exceptions exist in atypical situations, see ibid., n. 52 et seq.

57 AG Szpunar - Eturas, n. 68. The Court did not deal with the distinction between restrictions by object and by effect.

$58 \quad$ Restrictions by object are always appreciable, see ECJ, 13.12.2012, C-226/11 - Expedia, ECLI:EU:C:2012:795, n. 35-37. The thresholds of the De Minimis Notice therefore do not apply, see European Commission, Notice on 
before the restriction was implemented, or if they sold any travel products via the E-TURAS system afterwards. ${ }^{59}$ The category of restrictions by object substantially lowers the evidentiary requirements. No proof of the negative effects of the behaviour in question in the markets is necessary. Legal orders which do not have a comparable allocation of the burden of proof have considerable difficulties in proving a violation of Competition Law if competition with respect to other competitive parameters still exists.

However, the difference between restrictions by object and by effect is blurred in cases of concerted practices. ${ }^{60}$ As we have seen, the accusation of concerted practices is dropped if the undertaking in question can show that it systematically applied higher discounts than provided for by the computerised system. In this sense, the effect in the market plays a major role even in cases of horizontal price coordination which normally constitute a restriction by object for which no effects in the market have to be shown. In our view, the concept of concerted 'practices' indeed requires more openness to the effects of a certain behaviour. It is certainly true that also in the case of an 'agreement', the restrictive object cannot be exclusively deduced from the contents of this agreement but has to be assessed against the whole economic and legal context of that agreement. ${ }^{61}$ However, despite the helpful presumptions, it is always necessary to prove a conduct subsequent to concertation in order to find concerted practices. Normally, cases involving concerted practices are therefore more fact-based than restrictions of competition by defined agreement. Nonetheless, the fundamental difference between restrictions by object and by effect should not be disregarded. Once a concerted practice has been found which "reveals in itself a sufficient degree of harm to competition"62 there is no need to examine its effects. ${ }^{63}$ Thus, the higher evidentiary requirements in cases of concerted practices only relate to the coordination between undertakings, but not to the relationship between coordination and the restriction of competition, which is subject to the object/effect distinction regardless of agreements or concerted practices.

agreements of minor importance which do not appreciably restrict competition under Article 101(1) of the Treaty on the Functioning of the European Union, OJ 2014 C 291/1, n. 2, 13. However, the appreciability-test continues to apply when it comes to the question if trade between Member States may be affected, see European Commission, Guidelines on the effect on trade concept contained in Articles 81 and 82 of the Treaty, OJ 2004 C 101/81.

$59 \quad$ AG Szpunar-Eturas, n. 70.

60 See e.g. Schröter/Voet van Vormizeele, in: Schröter/Jakob/Klotz/Mederer (eds.), Europäisches Wettbewerbsrecht, $2^{\text {nd }}$ ed., Baden-Baden 2014, Art. 101 AEUV, n. 62; Whish/Bailey, Competition Law, 8th edition, Oxford 2015, p. 119.

$61 \quad$ ECJ, 11.9.2014, C-67/13 P - Groupement des cartes bancaires/Commission, E-CLI:EU:C:2014:2204, n. 53.

62 See the definition of "restriction by object" in ECJ, 11.9.2014, C-67/13 P - Groupement des cartes bancaires/Commission, E-CLI:EU:C:2014:2204, n. 57.

63 Emmerich, in: Immenga/Mestmäcker (eds), Wettbewerbsrecht Band 1.EU/Teil 1, $5^{\text {th }}$ ed., Munich 2012, Art. 101 Abs. 1 AEUV, n. 95. 


\section{Cartel Facilitators}

A special characteristic of the case is that Eturas, the right-holder of the E-TURAS booking system is not active on the market of the travel agencies which use this system. The Lithuanian Competition Council nevertheless concluded that Eturas had infringed Art. 101(1) TFEU since it had played a role in facilitating the discount coordination. The national court does not submit a preliminary question concerning liability of cartel facilitators. Consequently, the Advocate General only mentions this problem and proceeds to some distinctions regarding existing case law. ${ }^{64}$ The ECJ does not take a stance either, ${ }^{65}$ though it is clear from recent case law that the Court affirms the liability of cartel facilitators. In the AC Treuhand case, it has argued that Art. 101(1) TFEU covers all agreements and concerted practices restricting competition "irrespective of the market on which the parties operate, and that only the commercial conduct of one of the parties need be affected by the terms of the arrangements in question". ${ }^{66}$ In order to guarantee the 'full effectiveness' of Art. 101(1) TFEU, ${ }^{67}$ a firm which provides services aiming at the attainment of the anti-competitive objects of its contractual partners is also guilty of violating the cartel prohibition. ${ }^{68}$

Nonetheless, these recent developments are not even pertinent in the Eturas case. Eturas is not a consultancy firm like AC Treuhand, but is active on a market which is upstream to the cartel market. ${ }^{69}$ The online booking system is used by travel agencies to sell travel bookings on their websites and apparently allows to take influence on the amount of rebates. Therefore, the judgment is convincing insofar as it includes Eturas into the circle of cartel perpetrators.

\section{The Role of Presumptions in Competition Law}

The Eturas judgement is a milestone for the question of proof and evidence in Competition Law. In the field of public enforcement (be it under administrative or criminal law ${ }^{70}$ ), it is the task of the authorities to investigate the facts and to adduce evidence. Moreover, the presumption of innocence requires that everyone who has been charged "shall be presumed innocent until proved guilty

\footnotetext{
64 AG Szpunar-Eturas, n. 42.

65 See ECJ-Eturas, n. 15-16, where the decision of the Lithuanian Competition Council is reported without further analysis.

66 ECJ, 22.10.2015, C-194/14 P - AC Treuhand/Commission, ECLI:EU:C:2015:717, n. 35.

$67 \quad$ ECJ - AC Treuhand, n. 36.

68 ECJ - AC Treuhand, n. 37-39.

69 See the distinguishing by AG Szpunar-Eturas, n. 42. In the AC Treuhand case, Advocate General Wahl rejected the liability of mere service providers (contrary to the later Court decision), but reserved this finding to companies not trading on the relevant market (for the cartel) or on related markets, see the Opinion of Advocate General Wahl in $A C$ Treuhand/Commission (C-194/14 P, ECLI:EU:C:2015:350), for example n. 61 et seq. and the preceding headline. In the Eturas case, this narrow interpretation would not change the legal assessment since Eturas is not a mere service provider helping to implement a cartel, but the firm is active on an upstream market.

$70 \quad$ For the qualification of Competition Law fines and the consequences under Art. 6 of the European Convention on Human Rights see ECtHR, Case no. 43509/08 of 27 September 2011 - Menarini Diagnostics.
} 
according to law" (Art. 48(1) Charter of Fundamental Rights of the European Union and Art. 6(2) European Convention on Human Rights). On the other hand, public procedures serve a general interest and have to be effective. It is therefore recognised that presumptions can be used not only in administrative but also in criminal law if they respect certain conditions. The European Court of Human Rights has clarified that the presumption of innocence "requires States to confine them [scil. presumptions] within reasonable limits which take into account the importance of what is at stake and maintain the rights of the defence" ${ }^{71}$

In the Eturas judgment, the ECJ follows this path. It deduces from the presumption of innocence that awareness of the system notice cannot be inferred from the mere dispatch of the message. However, a presumption of awareness may be based on "other objective and consistent indicia". ${ }^{72}$ In this context, the Court develops a balanced approach exploring the middle ground between the presumption of innocence and the effectiveness of the application of Competition Law on the one hand, and between the EU competence for basic rules of evidence and the national competence for the assessment of evidence on the other. The result is a complicated mechanism which does not always make clear the extension of the procedural autonomy of the EU Member States. The guidelines are even more complex as the case is about concerted practices which require an even more careful analysis than 'simple' or 'straightforward' agreements.

What is made perfectly clear, however, is that the principle of effectiveness requires rules on proof and evidence which "must not render the implementation of EU competition rules impossible or excessively difficult". ${ }^{73}$ Therefore, not only direct evidence, but also indicia have to be admitted if they are objective and consistent. In this context, it is possible to establish presumptions provided that the firms have the possibility to rebut them. For this purpose, no "excessive or unrealistic steps" must be required. ${ }^{74}$ In our view, these principles should be interpreted in the following sense: the rebuttal of presumptions used by competition authorities and courts should not require full proof of the contrary. ${ }^{75}$ Presumptions in this context should be regarded as prima facie or res ipsa loquitur evidence where the rebuttal simply requires the creation of serious and reasonable doubts. ${ }^{76}$

\footnotetext{
71 ECtHR, Case no. 10519/83 of 7 October 1988 - Salabiaku v. France, n. 28.

ECJ - Eturas, n. 39-40.

ECJ-Eturas, n. 35.

ECJ - Eturas, n. 41.

AG Szpunar - Eturas, n. 99.

For more details see Andreas Heinemann, Access to Evidence and Presumptions - Communicating Vessels in Procedural Law, in: Hüschelrath/Schweitzer (eds.), Public and Private Enforcement of Competition Law in Europe Legal and Economic Perspectives, Berlin, Heidelberg 2014, p. 167, 177 et seq.
} 


\section{The Role of Computer Systems in Competition Law}

The Eturas judgment marks the mere beginning of Competition Law analysis with respect to computer-based cooperation strategies. At the heart of the case there is a system notice informing the users of an online booking system about the restriction of discounts accompanied by a technical restriction on discount rate entry into the system. Although such a system notice may not be a "usual channel for commercial communication" and less intense than e-mail contact, ${ }^{77}$ it may be a sufficient basis for concerted practices aiming at a restriction of competition. It all depends on the 'awareness' of the firms connected to the booking system with respect to the discount cap. The ECJ clearly states that without such awareness the "participation in a concertation cannot be inferred from the mere existence of a technical restriction implemented in the system [...], unless it is established on the basis of other objective and consistent indicia that it tacitly assented to an anticompetitive action. ${ }^{78}$

Thus, the essence of the judgment seems to be that technology alone cannot violate the cartel prohibition, and that assent of the respective firm is required. This leads to the more fundamental question of how Competition Law analysis should proceed if the practical functioning of a computer algorithm has become so autonomous that interference of firms and their employees is no longer necessary in order to influence prices of competing (or vertically related) firms. Should Competition Law liability in a machine-controlled environment still depend on 'awareness' or should other, more adapted criteria be developed?

In defence of the 'awareness' prerequisite, one could point to the fact that at least at the time of implementation of the computer system in question, an anti-competitive 'meeting of the minds' must have occurred, which may be attributed to the whole life-span of the system, even if the participating firms were not directly involved in the maintenance and the updating of that system. Yet how can initial awareness be proven if no information is available other than the connection of the firm in question to the computer system? In our view, the integration of a firm into a computer system which fixes prices (no matter if it concerns gross price, discounts, other deductions, surcharges, net prices etc.) with competitors (or which practices illegal vertical price maintenance ${ }^{79}$ ) is sufficient in order

\footnotetext{
77 This is at least the opinion of AG Szpunar-Eturas, n. 60.

$78 \quad$ ECJ - Eturas, n. 45.

79 See the Swiss case "Hors-Liste": The Swiss Competition Commission had found vertical price fixing based on the automatical (although alterable) transfer of price recommendations from wholesalers to retailers by means of a database (Decision of 2 November 2009, Recht und Politik des Wettbewerbs 2010/4, 649). The decision is not yet final. The Federal Supreme Court of Switzerland affirmed the applicability of the Swiss Competition Act (Decision of 28 January 2015, BGE 141 II 66) and remanded the case to the Swiss Federal Administrative Court which will have to decide on substance now.
} 
to establish a restrictive agreement or concerted practice. If pricing is completely delegated to software (without any need of administrator notices) with the object or effect of harmonising prices between competitors (or to impose vertical price fixing), the 'Cartel of the Machines' amounts to a cartel between undertakings. In these cases, traditional meetings or forms of communication are replaced by an algorithm which renders direct concertation superfluous. This result is not influenced by the fact that prices can still be modified by human intervention. If such interference does not take place, the goal of setting aside competitive pressure is achieved. Therefore, the delegation of competitors' pricing decisions to a unified computer system should constitute indirect evidence leading to a (rebuttable) presumption of a concerted practice.

The significance of computer systems in Competition Law analysis will certainly increase considerably over time. ${ }^{80}$ As is usually the case with technological developments, Competition Law has to adapt to the new environment. ${ }^{81}$ The consequences are frequently unclear and contested, and there will be grey areas. ${ }^{82}$ In the context of the formation of cartels, however, the situation is less complicated. Here, only the medium of concertation changes. Instead of meetings, phone calls or email exchanges, a computer system can be programmed in order to fix prices or at least - as in the case at hand - to cap discounts. For Competition Law to remain effective, it is important to cover new forms of coordination. Otherwise, the independence of economic actors would be jeopardised by the sophisticated tools made available by the new technologies.

80 The first assessments of the future of Competition Law in the context of autonomous computer systems have been submitted. See Ariel Ezrachi/Maurice E. Stucke, Artificial Intelligence \& Collusion: When Computers Inhibit Competition, The University of Oxford Centre for Competition Law and Policy Working Paper CCLP (L) 40 (with references to relevant US case law); Salil Mehra, Antitrust and the Robo-Seller: Competition in the Time of Algorithms, Minnesota Law Review (forthcoming).

$81 \quad$ For the digital world see Rupprecht Podszun, The More Technological Approach: Competition Law in the Digital Economy, in Surblyte (ed.), Competition on the Internet, Berlin/Heidelberg 2015, p. 101 et seq.

82 See the example of Ezrachi/Stucke (supra note 80, at II D) of autonomous machines which are programmed on optimizing profitability but which may (but do not necessarily) lead to collusion. 